\title{
Survival by a thread: knowledge owed to single authors
}

\author{
LEOFRANC Holford-STREVENS* \\ University of Oxford \\ United Kingdom
}

\begin{abstract}
Resumo. Sobrevivencia por um fio: conhecimento adquirido de autores isolados. Neste artigo examino a sobrevivência do conhecimento da antigüidade aos tempos modernos, considerando: um capítulo de Macróbio que preserva material que se sabe ter sido parte do oitavo livro, hoje perdido, de Aulo Gélio; a história - ainda evocada por teóricos do teatro - do ator Polus, que representou a Electra de Sófocles segurando a urna com as cinzas de seu próprio filho, preservada somente por Gélio; e as notícias favoráveis sobre Espártaco em Plutarco e em outros escritores, que todos alegam recuar até Salústio.

Palavras-chave. Arte teatral; Aulo Gélio; Espártaco; Macróbio; Plutarco; Polus; Salústio; transmissão; único autor.
\end{abstract}

Hac noctu filo pendebit Etruria tota.

This verse, now neatly docketed with the cumulative line-number 142 in Otto Skutsch's edition of Ennius' Annales, itself depends on a thread. It is cited, along with noctu concubia also from Ennius, noctu multa from Claudius Quadrigarius, and adverbial nox from the Twelve Tables, by Macrobius, Saturnalia 1. 3. 16, 4. 17-19:

Ergo noctu futura, cum media esse coeperit, auspicium Saturnaliorum erit, quibus diecrastini mos inchoandi est. [Auienus uerborum nouitatem miratur.] . . Reliqua autem uerba quae Auieno nostro noua uisa sunt. ueterum nobis sunt testimoniis adserenda. Ennius enim, nisi cui uidetur inter nostrae aetatis politiores munditias respuendus, 'noctu concubia' dixit his uersibus:

qua Galli furtim noctu summa arcis adorti moenia concubia uigilesque repente cruentant. ${ }^{1}$

quo in loco animaduertendum est non solum quod 'noctu concubia', sed

* 67 St. Bernard's Road, Oxford, OX2 6EJ, Great Britain.

${ }^{1}$ Verses 227-8 in The Annals of Quintus Ennius, ed. Отто SкUтsсн (Oxford, 1985). 
quod etiam 'qua noctu' dixerit. Et hoc posuit in annalium septimo in quorum tertio clarius idem dixit:

hac noctu filo pendebit Etruria tota. ${ }^{2}$

Claudius etiam Quadrigarius annali tertio: 'Senatus autem de nocte conuenire, noctu multa domum dimitti. ${ }^{3}$ Non esse ab re puto hoc in loco id quoque admonere, quod decemuiri in duodecim tabulis inusitatissime 'nox' pro 'noctu' dixerunt. Verba haec sunt: 'Si nox furtim faxit, si im occisit iure caesus esto.' In quibus uerbis id etiam notandum, quod ab eo quod est 'is' non 'eum' casu accusatiuo sed 'im' dixerunt.

This whole passage is manifestly borrowed from the eighth book of Aulus Gellius' Attic Nights, itself lost apart from the chapter summaries: see Noctes Atticae 8. 1. cap. 'Hesterna noctu' rectene an cum uitio dicatur, et quaenam super istis uerbis grammatica traditio sit; item quod decemuiri in XII tabulis 'nox' pro 'noctu' dixerunt.

Why 'manifestly' if the book is lost? Because the summary indicates that Gellius discussed the use of noctu as an ablative with adjectival qualification and explicitly quoted the decemvirs' construction of nox; the inference is confirmed by the fact of citing not merely Ennius but Claudius Quadrigarius, nearly half of whose surviving fragments come from Gellius, and even by the little note on a new topic appended at the end, pointing out the use of im instead of eum, which is completely in Gellius' manner. In addition there are linguistic echoes. ${ }^{5}$ It is also notorious that Macrobius plagiarized whole chapters of Gellius, whom he never names; indeed, having exhausted book 8 , chapter 1 , he immediately proceeds to mine book 10 , chapter 24 for discussion of diecrastini.

Ennius' Annales, Gellius' source if any, and his own text in this chapter all being lost, our knowledge of this verse is due entirely to the accident of

${ }^{2}$ Verse 142 Skutsch.

${ }^{3}$ Fr. 45 in Historicorum Romanorum reliquiae, i, ed. Hermann Peter, 2nd edn. (Leipzig, 1914, repr. Stuttgart, 1967), 221 = fr. 44 in L'Annalistique romaine, iii: L'Annalistique récente, l'autobiographie politique, ed. Martine Chassignet (Paris, 2004), 29 and Diefrühen römischen Historiker, ii: Von Coelius Antipater bis Pomponius Atticus, ed. Hans BeCK and Uwe Walter (Texte zur Forschung, 77; Darmstadt 2004), 137-8.

${ }^{4}$ I 17 in Roman Statutes, ed. M.H. Crawford, 2 vols. (London, 1996), ii. $578=$ VIII 12 in Fontes iuris Romani antiqui, ed. Karl Georg Bruns, rev. Otto Gradenwitz, 7th edn. (Tübingen, 1969), 31 and Fontes iuris Romani antejustiniani, i: Leges, ed. Salvatore RicCOBONo, 2nd edn. (Florence, 1968). 37.

${ }^{5}$ animaduertendum est, cf. Gell. 9. 1. 8. 10. 11. 9; annali tertio, cf. Gell. 1. 7. $9(2 \times), 1$. 16. cap., 2. 2. 13, 2. 19. 7, etc.; non esse ab re, cf. Gell. 1. 26. 4, 2. 2. 12, 11. 1. 6; id quoque

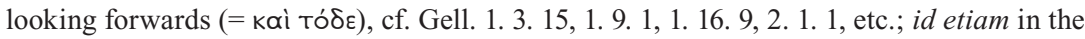
same sense, cf. Gell. 1. 17. 6, 2. 24. 13, 3. 10. 15, 5. 2. 4, etc.; ab eo quod est, cf. Gell. 2. 6. 5, 2. 17. $11,3.19 .5,4.16 .1$, etc. 
Macrobius' choosing to quote Gellius. The same is true of the verses that the knight $\mathrm{D}$. Laberius delivered to avenge the humiliation of being made by Caesar to perform in one of his own mimes: with Noctes Atticae 8. 15. cap. 'Quibus modis ignominiatus tractatusque sit a C. Caesare Laberius poeta; atque inibi appositi uersus super eadem re eiusdem Laberii' cf. Macrobius, Saturnalia 2. 7. 1-5, where the verses (Laberius $98-124$ Ribbeck $^{2}$ ) are cited in full.

In the surviving bulk of Gellius there is also much known only from him and through him from Macrobius, such as Cato's story of the boy Papirius who told an ingenious lie when pestered by his mother to betray a secret (Noctes Atticae 1. 23 Macrobius, Saturnalia 1. 6. 19-26); it is indeed to Macrobius that in earlier times this story seems to be mainly credited, and it is surely Johannes Pontanus' edition of his works that inspired his brother Pieter Isaacsz. to paint the climatic scene, but without Gellius it would not have been known at all. A less familiar example may be the fact that the second day of the month in which this paper was given, August 2004, was the 2219th anniversary of the battle of Cannae, fought on the fourth day before the Nones of Sextilis in the consulate of Lucius Aemilius Paullus for the second time and Marcus Terentius Varro. ${ }^{6}$ The year is famous; but how do we know the date? Not from a combination of literary texts and inscriptions, as we do that of the dies Alliensis, but only from Aulus Gellius, Noctes Atticae 5. 17. 3-5 and, copying from him, Macrobius, Saturnalia 1. 16. 26; Gellius himself had it, as one might expect, from Claudius Quadrigarius.?

Ante diem quoque quartum Kalendas uel Nonas uel Idus tamquam inominalem diem plerique uitant. Eius observationis an religio ulla sit tradita, quaeri solet. Nihil nos super ea re scriptum inuenimus, nisi quod Q. Claudius annalium quinto cladem illam pugnae Cannensis uastissimam factam dicit ante diem quartum Nonas Sextiles.

On other occasions, Gellius is the borrower from a previous author, without whom the story would have been lost to us. This is the case with the story of Dolabella and the Woman of Smyrna, which Gellius, Noctes Atticae 12. 7, adopts or rather adapts from Valerius Maximus, Facta et dicta memorabilia 8. 1. amb. 2, and about which I have written at length; ${ }^{8}$ it owes

\footnotetext{
${ }^{6}$ What relationship that date bore to 2 August $216 \mathrm{BC}$ on the retrojected Julian calendar is open to debate.

${ }^{7}$ Fr. 53 Peter (n. 3), 222 = fr. 52 Chassignet (n. 3), 31 and BeCK-Walter (n. 3), 140.

${ }^{8}$ See Leofranc Holford-Strevens, 'Getting Away with Murder: The Literary and Forensic Fortune of Two Roman Exempla', International Journal for the Classical Tradition, 7 (2000-1), 484-514.
} 
its subsequent literary fortune to Gellius, but its currency in Renaissance jurists to Valerius, to whom the credit is due for its preservation.

If, however, we prefer a stricter definition, on which the single author is the only author surviving from antiquity to treat of the subject, we may consider a story indeed reported by only one author, with no indication of his source, that has achieved a familiarity in modern times outside the ranks of classical scholars, and for which Gellius is the only source. This is the tale of the actor Polus, who carried his son's ashes in the urn over which, as Sophocles' Electra, he had to weep for Orestes (Noctes Atticae 6. 5): ${ }^{9}$

Histrio in terra Graecia fuit fama celebri, qui gestus et uocis claritudine et uenustate ceteris antistabat: nomen fuisse aiunt Polum, tragoedias poetarum nobilium scite atque asseuerate actitauit. Is Polus unice amatum filium morte amisit. Eum luctum quom iam satis uisus est eluxisse, rediit ad quaestum artis. In eo tempore Athenis Electram Sophoclis acturus, gestare urnam quasi cum Oresti ossibus debebat. Ita compositum fabulae argumentum est, ut ueluti fratris reliquias ferens Electra comploret commisereaturque interitum eius existimatum. Igitur Polus, lugubri habitu Electrae indutus, ossa atque urnam ex sepulcro tulit filii et quasi Oresti amplexus oppleuit omnia non simulacris neque imitamentis, sed luctu atque lamentis ueris et spirantibus. Itaque cum agi fabula uideretur, dolor actus est.

We do not know who supplied this story; not even the mad source-critics of the nineteenth century thought they did, though Carl Hosius in his Teubner edition of 1903 guessed at Gellius' great friend the polymath Favorinus. But from the Renaissance onwards the tale has enjoyed wide currency. The poetic theorist Lorenzo Giacomini took it at face value: one's own troubles affect one far more than other people's, and therefore do not require us to contrive a show of emotion. ${ }^{10}$ Lipsius quoted it in De constantia as an analogue for persons who bemoaned their private ills under cover of their country's ${ }^{11}$ in a more Hellenized age he would no doubt have thought first of Briseis' handmaidens,

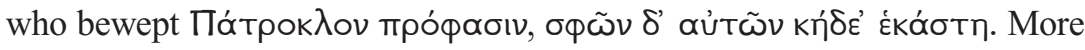
often, however, it has been told in its own context, that of the stage.

When Joost van den Vondel published his version of Sophocles' Electra, it was preceded by the tale of Polus in Dutch translation, not only from Gellius, but also from Lipsius 'the light of his age's learning', carefully cut

${ }^{9}$ I hope to publish a fuller study of this anecdote elsewhere.

10 'Del furor poetico' (delivered to Accademia degli Alterati, 1587), in Orationi e discorsi (Florence, 1597), 53-73 at 68; he alludes to Davus' words at Terence, Andria 794-5.

${ }^{11}$ De constantia (Antwerp, 1584), 1. 8, p. 23. 
out of its context so that only the story remained and not the application. ${ }^{12}$ In the same year, Georges de Scudéry - who turns the singularly beloved son into an only son - commended Polus as a model for modern actors to follow, along with Aesopus, who had been so carried away by the rage of his character, King Atreus, that he killed a slave who accidentally got in his way, and unnamed actors said to have been so moved by their sad parts that they were still weeping when they left the stage):

Mais nous pouuons encor adiouter icy, vn Polus Comedien Grec, qui representant une Tragedie de Sophocle intitulée Electre, au lieu de l'Vrne d'Oreste, aporta sur le Theatre, celle ou estoyent effectiuement, les cendres d'vn fils vnique que cet Acteur auoit perdu depuis peu : si bien qu'il representa naifuement sa propre douleur, sous le nom feint de celle d'vn autre. Voila les Exemples que doiuent suiure et imiter nos Comediens ... ${ }^{13}$

From then on the story becomes a standard topos for writers on the theory of acting, as illustrating the Horatian principle si uis me flere, dolendum est primum ipsi tibi.

Whether this is a valid principle is much debated: at the opposite extreme one school of thought holds that, in the midst of the most affecting speech, the performer, if required by the action to turn his or her back on the audience, should be capable of pulling a face at other members of the cast in the wings. Attitudes to the story have likewise varied: the approval of Scudéry and of Michel le Faucheur in the seventeenth century finds English and German echoes in the eighteenth, ${ }^{14}$ but the First Speaker in Diderot's Paradoxe sur le comédien, confronted by the story, reacts with scorn:

Et vous croyez que Polus dans ce moment parla sur la scène comme il aurait parlé dans ses foyers? Nos, non. Ce prodigieux effet, dont je ne doute pas, ne tint ni aux vers d'Euripide, ni à la déclamation de l'acteur, mais bien à la vue d'un père désolé qui baignait de ses pleurs l'urne de son propre fils. Ce Polus n'était peut-être qu'un médiocre comédien ... ${ }^{15}$

${ }^{12}$ Joost van den Vondel, Elektra van Sophokles, Treurspel (Amsterdam, 1639), in De werken van Vondel, ed. F.F.M. STERCK et al., 10 vols. (Amsterdam, 1927-37), iii. 644.

${ }^{13}$ Georges de Scudéry, L'apologie du théâtre (Paris, 1639), 86.

${ }^{14}$ [Michel Le Faucheur], Traitté de l'action de l'orateur: ou de la prononciation et du geste (Paris, 1657), 204-6; Charles Gildon, The Life of Mr. Thomas Betterton (London, 1710), i. 68-9, based on an English translation of Le Faucheur, An Essay upon the Action of an Orator; as to his Pronunciation \& Gesture (London, [?1680]), 185-7; Johann Christoph GotTsched, Versuch einer Kritischen Dichtkunst (Leipzig, 1751), 21.

${ }^{15}$ Ed. Jane Marsh Dieckmann, in Euvres complètes, ed. Herbert Dieckmann, Jean Varloot, et al., xx (Paris, 1995), 127. 
Indeed, he denies the Horatian principle, maintaining 'Ce que la passion elle-même n'a pu faire, la passion bien imitée l'exécute'. ${ }^{16}$

Diderot extended his repudiation to public speaking, for which the orthoepist John Walker had found the anecdote no less apt $;{ }^{17}$ but when, contemporaneously with the last-named, the article on the actor Jan Punt in a biography of prominent Dutchmen and Dutchwomen cited the tale with the comment 'it must be an extremely lively imagination that can become the plaything of its own artifices', ${ }_{18}$ a colleague of Punt's, a 'currently resting actor' by the name of Marten Corver, wrote an open letter setting out to demonstrate in general that the author was totally unqualified to write about the Dutch stage, and in particular that this comment 'leads me to believe that your knowledge concerning the practice of us actors is very slight'; ${ }^{19}$ by adding and correcting details in the narrative, he indicates for his better-educated readers that the biographer's knowledge of classical literature is also zeer gering.

After a long period of neglect in the nineteenth century, the story was revived by Bertold Brecht, who naturally has no time for such empathizing: indeed Brecht the writer makes Brecht the speaker call the proceeding barbaric, without feeling obliged to justify that opinion, and lets Helene Weigel not only suggest that favourable reviews of another actor would be just as efficacious, but ask hard-headed- or hard-heartedly: 'Vielleicht war sein Sohn ein Schurke. Er mag trotzdem leiden, aber warum soll ich es?' ${ }^{20}$ By contrast, it finds favour with Lee Strasberg ${ }^{21}$ Polus has even been called

${ }^{16}$ Ibid. 128. He also dismisses Aesopus as 'un fou que le tribun devait envoyer surle-champ au mont Tarpéien' (p. 127); whatever the deficiencies in Diderot's understanding of Roman criminal procedure, he appears to have killed off Aesopus as an exemplum, but Polus is still alive and well.

${ }^{17}$ Elements of Elocution, 2 vols. (London, 1781), ii. 276: 'In this exigence, it may not, perhaps, be unprofitable, to call to our assistance the device of the ancient Grecian actor Polus; who, when he had the part of Electra to perform, and was to represent that princess weeping over the ashes of her brother Orestes, ordered the urn, which contained the ashes of his dear and only son to be brought upon the stage, and by this means excited in himself the pitch of grief with which he wished to affect his audience.'

${ }^{18}$ [Simon STIJL], 'Het Leven van Jan Punt', Levensbeschryving van eenige voornaame meest Nederlandsche mannen en vrouwen, ix (Amsterdam and Harlingen, 1781), 1-103 at 19: 't Moet wel eene allerlevendigste verbeelding zyn, die dus het speeltuig van haare eigene kunstgrepen worden kan.'

${ }^{19}$ MARTEn CORVER, 'thans rustend Tooneelspeler', Toneel-aantekeningen vervat in een omstandigen Brief, Aan den Schrijver van het Leven van Jan Punt (Leiden, 1786), 30: ' . . . doet mij geloven, dat uw kennis wegens de practijk van ons Tooneelspelers zeer gering is.'

20 'Gespräch über die Nötigung zum Einfühlung', Schriften zum Theater (Frankfurt am Main: Suhrkamp, 1957, repr. 1978), 210-11.

${ }^{21}$ Encyclopaedia Britannica, 15th edn. (Chicago, 1992), xxviii. 525. 
'in a way the first Method actor on record', ${ }^{22}$ and credited with a Stanislavskian concern for truth, ${ }^{23}$ though a French theatrical scholar, less enamoured of these doctrines, Patrice Pavis points out that not even Stanislavsky or the Method actors actually follow him; ${ }^{24}$ the story is even used by a conservative US Christian as a parallel to a reconstruction of David's pretended madness at the court of King Achish in Gath. ${ }^{25}$

By no means all the authors cited have gone back to Gellius, even when they name him, or got all the details right: Gottsched not only repeated Scudéry's mistake about Polus' son, but gave the actor Roman citizenship, Diderot confuses Sophocles with Euripides and supposes that Athenian tragedy was performed in a hall; Brecht, by misreading Gottsched, takes the source of the story to be Cicero. But these errors demonstrate that the exemplum preserved by a single author has become common property.

Before leaving this story, I should like to leap back a few hundred years to perhaps the most interesting use of all, that made by Thomas Goffe in The Tragedie of Orestes, performed at Christ Church, Oxford, in the early seventeenth century and published in 1633; none other than Orestes, in a conceptual echo of Hamlet's 'What's he to Hecuba?', contrasts his own and the actor's capacity for expressing grief (Act III, sc. v):

There was a player once vpon a stage,

Who striuing to present a dreery passion,

Brought out the vrne of his late buried sonne,

It might the more affect him, and draw teares:

Not acting of a part, but really

In a true cause hauing my Fathers bones,

His hollow scull, yet crawling full of worms,

I cannot weepe, no not a teare wil come. ${ }^{26}$

22 'Was ist Method Acting?', website of the Actors Workshop Vienna, promoting seminar of 20-5 August 2004, http://www.actorstraining.com/themethod/method.htm (last accessed on 13 March 2005).

${ }^{23}$ John H. Bartlett, 'Thomas Betterton 1635-1710, the Great Actor of the Restoration' (1995, revised), http://www.geocities.com/scriblerus_uk/Betterton.html (last accessed on 13 March 2005).

${ }^{24}$ PAtrice Pavis, L'Analyse des spectacles; théâtre, mime, danse, danse-théatre, cinéma (Paris, 1996), 57-8; Portuguese translation at http://www.theatro.ocrocodilo.com.br/ator.html (last accessed on 13 Mar. 2005).

${ }^{25}$ JefF TAYlor, 'The Craft of Acting, the Art of Acting and their Relationship to the World of the Work', (1997, updated 13 July 2002), on Telling the Truth Project website, http://www.leaderu.com/humanities/craft_acting.html (last accessed on 13 March 2005); see 1 Sam. (= I Reg.) 21: 13.

${ }^{26}$ The Tragedie of Orestes (London, 1633), sig. E2 $2^{\mathrm{rv}}$. 
We are used to admiring the metatheatrical complexity of Elizabethan and Jacobean plots in which, since only males were admitted to the stage, a youth plays a woman, say Viola, pretending to be a youth, say Cesario; but what is that complexity to this? It is worthy of Tom Stoppard himself: an actor, feigning grief over a stage prop feigned to represent a skull, represents a character (Orestes) who while really grieving over a real skull (his father's) contrasts his own inability to produce the symptoms of that grief with another actor's (Polus') successful use of his own real grief over a funerary urn feigned to be a stage prop in order to feign the no less real grief of a character (Electra) over the bones of the first character (Orestes).

I now turn to another author, to whom alone I shall argue that we owe not indeed our knowledge, but our evaluation of a historical personage. That personage is Spartacus. I am not speaking about the objective importance of the war, magnum quidem ac uehemens, as Cicero says when denying Verres credit for keeping it out of Sicily (In Verrem II, 5. 5), or seruili bello taetro periculosoque as he says a few years later when claiming that Pompey put an end to it (De imperio Cn. Pompei 30); my concern is with our view of the man. From Cicero one would acquire nothing but the image of a brutal and bloodthirsty bandit (e.g. Phil. 4. 15, 13. 22); the more favourable comments by his elder contemporary Varro, and his younger contemporary Diodorus the Siceliote, to which I shall come in due course, are too fleeting and insubstantial to start a myth. Other passing references tell us no more than that he was a bandit suppressed (as reading between the lines we could have gathered even from Cicero) not by Pompey but by Crassus. ${ }^{27}$

Livy's narrative is lost, and must be pieced together from the periochae to books 95-7 supplemented with all due caution from Florus, Ampelius, and Orosius. It is not even certain that Spartacus was made the ringleader ahead of Crixus, who is mentioned first in the periocha to 95: 'Crixo et Spartaco ducibus'. The focus is on the Roman performance, initially disastrous until Crassus saves the day; Spartacus is cruel and vindictive, putting on funeral games for his fallen officers in which Roman prisoners are made to fight as gladiators. And that is the general picture one derives from casual references both Greek and Latin.

Contrast the noble figure of Spartacus in Sallust, who attempts to prevent his troops from committing atrocities. Textual comparison with Plutarch shows resemblances between the account in the Life of Crassus and the surviving fragments of Sallust: in book 3 of the Historiae, Mauren-

${ }^{27}$ The ancient sources for Spartacus' rebellion are discussed by Giulia Stampacchia, La tradizione della guerra di Spartaco da Sallustio a Orosio (Pisa, 1976), and reproduced in full at p. 163-99. 
brecher's fragments fr. 98C ' . . neque sanctum aut nefandum quicquam fuit irae barbarorum et seruili ingenio. quae Spartacus nequiens prohibere multis precibus cum oraret, ..., 91 'ingenio ipse uirium atque animi', and 96D 'Crixo et gentis eiusdem Gallis atque Germanis obuiam ire et ultro $<$ of $>$ ferre pugnam cupientibus, contra Sparta $<$ co . . ' point in the direction

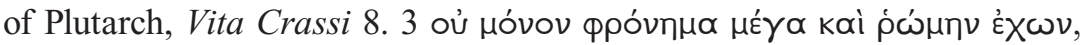

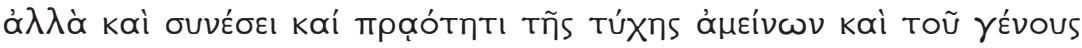

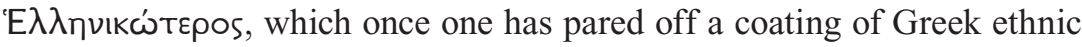
chauvinism matches perfectly Sallust's portrait of his humanity, and also of his opposition to rash attacks. Likewise fr. 94 Maurenbrecher 'Cossinius in proxima uilla lauabatur' seems to underlie Plutarch, Vita Crassi 8. 6

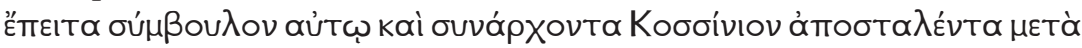

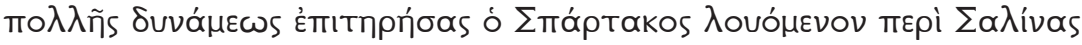

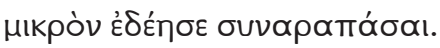

Indeed, it is commonly accepted that Sallust underlies Plutarch's narrative; Appian, as always, poses additional problems for the source-critic, but Sallustian matter is thought to be present. He reports that Spartacus would not admit gold and silver to this camp, only iron and bronze (Bellum Ciuile

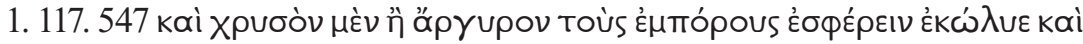

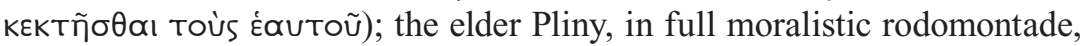
animadverts to the same decree (Historia Naturalis 33. 49):

pudet intuentem nomina ista, quae subinde noua Graeco sermone excogitantur insperso argenteis uasis auro et incluso, quibus deliciis pluris ueneunt inaurata quam aurea, cum sciamus interdixisse castris suis Spartacum, ne quis aurum haberet aut argentum. tanto plus fuit animi fugitiuis nostris!

Since Pliny is all too capable of such comments, we need not suppose that he needed a source for anything except the fact, even though Sallust was notorious for excoriating everybody's vices but his own. On the other hand, Appian's Spartacus, 'nobler Charakter' as well as a 'real representative des antiken Proletariats' as he may have been for Karl Marx ${ }^{28}$ is less humane, sacrificing 300 Roman prisoners to the dead Crixus (Bellum Ciuile 1. 117.

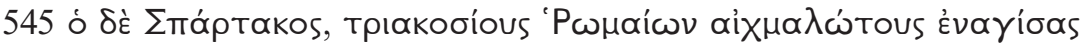



${ }^{28}$ Letter to Engels of 27 February 1861: Karl Marx - Friedrich Engels - Briefwechsel, iii (Moscow, 1937), 20; language-mixture as in the original. (I was reminded of this passage by Dr. Martin Hose.) By 1869 Marx had a different understanding of the ancient proletariat: see the closing paragraph of his preface to the second edition of Der achtzehnte Brumaire des Louis Bonaparte. 
Iulius. The latter story, though present in Suetonius (Div. Aug. 15: [Perusia capta] scribunt quidam trecentis ex dediticiis electos utriusque ordinis ad aram Diuo Iulio extructam Idibus Martiis hostiarum more mactatos) and Cassius Dio (48. 14. 4), and alluded to by Seneca (Clem. 1. 11. 1), is not in Appian, and indeed is hardly compatible with his circumstancial narrative of the capture in the fifth book of his Civil War; it would be interesting to know whether Octavian was being assimilated to Spartacus or Spartacus to Octavian.

Elsewhere, in another work War, Appian states that nearly all Italy fought alongside Spartacus (Bellum Mithridaticum 109. 517):

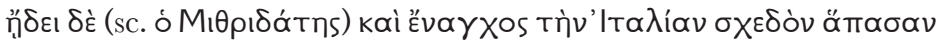

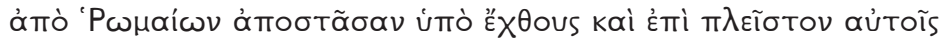

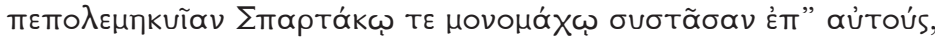

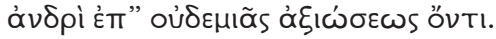

It has been suggested that the source was Asinius Pollio, the grandson of the praetor Marrucinorum, presumably by way of flashback in his history, which as we all know began ex Metello consule in $60 \mathrm{BC}^{29}$ If so, it was as false as Pollio's account of Cicero's death (Seneca maior, Suasoriae 6. 24, for the Italian cities did not join in the war; so indeed Appian tells us in

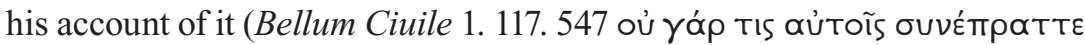

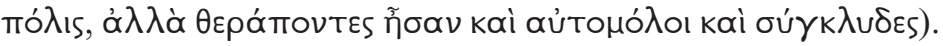

Varro, in a fragment quoted by Charisius (Ars grammatica 1, p. 170. 1920 Barwick) for the sake of the ablative innocente, had denied that Spartacus had done anything to merit being made a gladiator: Innocente Varro de rebus urbanis III: 'Spartaco innocente coniecto ad gladiatorium.' ${ }^{30}$.

A work on res urbanae was not the most obvious place for a detailed account of the revolt, rather a brief account, ${ }^{31}$ to which this ablative absolute is well suited, aimed at explaining why Pompey, irregularly and needing a crash course in senatorial procedure (Gellius, Noctes Atticae 14. 7. 2), became consul in 70 BC. Nevertheless Varro's words match well enough with Plutarch's comment that the gladiators were the victims of their purchas-

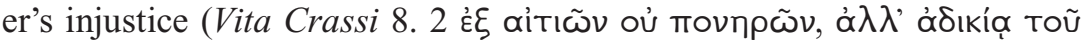

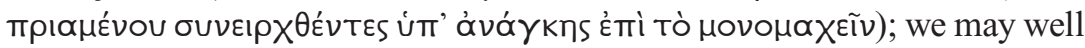
suppose that Sallust too made this point. Once the revolt had broken out, indeed, it was perfectly obvious that Cn. Lentulus Batiatus, the gladiators'

${ }^{29}$ Stampacchia (n. 27), 157; cf. Livy, periocha 73, Horace, Carmina 2. 1. 1.

${ }^{30}$ Book 3, fr. 1 in Historicorum Romanorum reliquiae, ed. Hermann Peter, i (Leipzig, 1906; repr. Stuttgart, 1967), 24. 
owner, was to blame: proximately for the lapse in security, but as further facts emerged for provoking the rebellion in the first place; that does not mean that had the slaves dutifully gone about their business, fighting until they were killed or discharged, anyone would have cared twopence about the justice or injustice of their treatment. It was, after all, something that happened all the time; nor were any reforms undertaken afterwards to ensure that no such further occasion for revolt was given. The response was far more Roman; six thousand crosses along the Appian Way from Rome to Capua, where the outbreak had started. If they were on both sides of the road, that means one cross every 65 metres.

Nevertheless, it has been argued that Plutarch's comment derives from Stoic teaching about the essential equality of freeman and slave; only one extant Stoic writer even speaks of Spartacus, and he not well (Lucan, Bellum ciuile 2. 552-4), but Poseidonius has been invoked both on this account and because Diodorus' remark on Spartacus' display of gratitude, barbarian that he was (Bibliotheca Historica 38/9. 21):

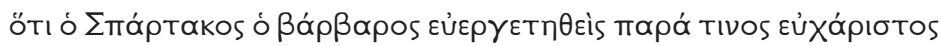

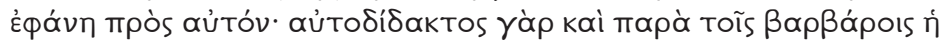

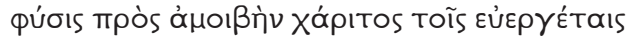

resembles a similar comment on slaves (34/5. 2. 40 ötı kaì Tapà тоĩs

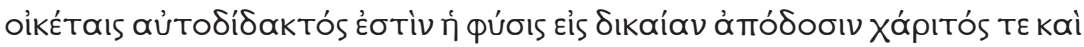

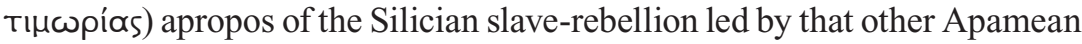
Eunus ${ }^{32}$ which even the sceptical Kidd accepts that Poseidonius described, ${ }^{33}$ while declining to follow Theiler in crediting him with Diodorus' whole account $;{ }^{34}$ nothing could be more absurd than to suppose that a Siceliote writing about a major event in Sicily had neither heard nor read a word about it save in a single history.

One may indeed be open to the possibility that Poseidonius made such an observation, even that he is also the source of Diodorus' comment in a completely different context (the prisoners (apparently captured at Numantia)

${ }^{31}$ Cf. Peter (n. 30), pp. xxxviii f.: 'Idem index Hieronymi "Rerum urbanarum III" eum scripsisse enumerat ..., quas cum omnes nimis largam materiem suppeditarent, sensu artiore tractatos esse per se elucet.' Book 1 ran from the regal period to at least the execution of M. Manlius Capitolinus (see fr. 1-2, p. 22).

${ }^{32}$ Stampacchia (n. 27), 139.

${ }^{33}$ I.G. KIDD, Posidonius, ii: The Commentary, (i) Testimonia and Fragments 1-149 (Cambridge, 1988), 293, 294-5, on F59 (= 136a in TheILER's edition, see next note).

${ }^{34}$ Willy Theiler, Poseidonios: Die Fragmente, ii: Erläuterungen (Berlin, 1972), 99; Diodorus' entire account is reprinted as F 136b-f, 137, 142-6. 
who kissed the soil of their native land, that even brutal barbarians feel such

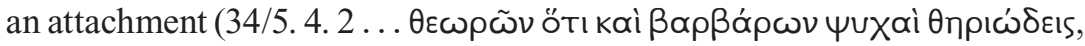

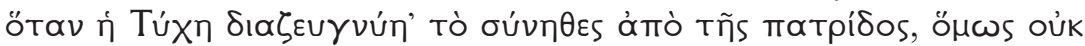

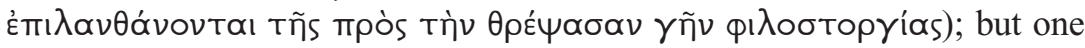
may more easily believe that he was so taken with these observations as to insert similar remarks wherever he saw an opportunity, than that Poseidonius continued his narrative down to Spartacus' rebellion. Theiler indeed denies, and Kidd doubts, that he prolonged his narrative beyond the mid- $80 \mathrm{~s} \mathrm{BC} .{ }^{35}$ Indeed, if the judgement in Diodorus that this was the greatest such rebellion

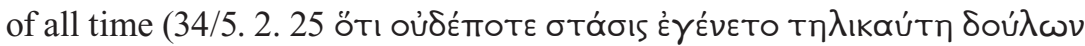

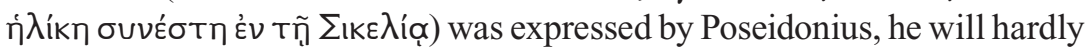
have written at length on a later and lesser event; but I dare not insist on that point, since Diodorus might have added it de suo.

In any case, it did not take a philosopher to notice that slaves and barbarians resent ill usage: the elder Cato, who could not have read the unborn Poseidonius even had he wished, concludes his denunciation of a brutal Roman magistrate with the words:

Set quantum luctum, quantum gemitum, quid lacrimarum, quantum fletum factum audiui! Serui iniurias nimis aegre ferunt: quid illos, bono genere gnatos, magna uirtute praeditos, opinamini animi habuisse, atque habituros dum uiuent? $?^{36}$

Those touches of nature that make the whole world kin are visible to any competent observer without need of a Poseidonius to point them out; I cite a Tudor English text, Edward Hall's Chronicle of the reign of Henry VII, concerning the Cornishman Michael Joseph, known as An Gôf ('the Smith'), ringleader of a rebellion in 1497 against the king's high taxes:

This Mighell ${ }^{37}$ Joseph, surnamed the black smyth one of the capteins of this donge hill ${ }^{38}$ and draffe sacked ${ }^{39}$ ruffians, was of such stowte stomack and haute courage, that at thesame time that he was drawen on the herdle ${ }^{40}$ toward his death, he sayd (as men do reporte) that for this

${ }^{35}$ Theiler (n. 34), 79; Kidd (n. 33), 277-80.

${ }^{36}$ De falsis pugnis, fr. 42 in $M$. Porci Catonis orationum reliquiae, ed. Maria Teresa Sblendorio Cugusi (Turin, 1982), 198-205 = fr. 58 in Oratorum Romanorum fragmenta liberae rei publicae, i: Textus ed. EnRICA Malcovati, 4th edn. (Turin, 1976), 26-7.

${ }^{37}$ Cf. Cornish Myghal = Michael.

${ }^{38}=$ dunghill.

${ }^{39}$ i.e. fit to be thrown into rubbish-bags.

${ }^{40}=$ hurdle; see Oxford English Dictionary s.v. hurdle, $n$., sense 1c: 'A kind of frame or sledge on which traitors used to be drawn through the streets to execution.' 
myscheuous and facinorous acte, he should haue a name perpetual and a fame permanent and immortal. So (you may perceaue) $)^{41}$ that desire and ambicious cupidite of vaine glorie and fame, enflameth, and encourageth aswel poore and meane persones, as the hartes ${ }^{42}$ of great lords and puyssant princes to trauayle and aspire to thesame. ${ }^{43}$

We are therefore brought back to Sallust, whose favourable presentation of the man, though not his troops, needs to be accounted for. The obvious comparison is with another public enemy Sertorius, who received some favourable notices in Sallust's history; both Spartacus and Sertorius successfully defied the generals of the Sullan order. It took those ambiguous characters Pompey and Crassus to beat them; the consequence was their joint, but in Pompey's case unconstitutional consulate, the undoing of the Sullan settlement, and all too soon the institution of the extraordinary commands that both confirmed the gap in military competence between Pompey and the optimates, and foreshadowed the coming and irreversible defeat of the Republic by the men of blood and iron. Sallust, who does not admire these men, blames the decadence of a ruling order that could not forestall their rise; against opponents with any claim to brain and character the lawfully elected generals were helpless.

The rebels had three leaders: Spartacus, Crixus, and Oenomaus, one Thracian and two Gauls. To my knowledge the latter two have hardly been romanticized even in France, but Spartacus has been a name to conjure with at least since the eighteenth century: commemorated in politics above all by the German Marxists who perished in a far briefer rebellion, but in the arts amongst others by Lessing, Khachaturian, and Kubrick. Nay more, despite his reluctance to perform in competitive entertainments he is commemorated in sport, long after the failure of the revolutionary state, not only by football clubs in Moscow and elsewhere, but by a Russian yacht-club so un-Marxist that its website proudly boasts its sponsorship of a voyage round the earth by a craft named after the Apostle Andrew. ${ }^{44}$ It is my contention that without Sallust none of this would have happened; that the reputation of Spartacus thus depends on a single author.

${ }^{41}$ By modern standards the parentheses are used illogically, as if the following 'that', subordinating what follows to 'perceaue' (= perceive), were not present.

${ }^{42}=$ hearts.

${ }^{43}$ Hall's Chronicle, ed. Sir Henry Eluis (London, 1809), 479-80.

${ }^{44} \mathrm{http}: / / \mathrm{www}$. spartak.ws/archive, last accessed on 14 March 2004. 
AвSTRACT. In this article I examine the survival of knowledge from antiquity to modern times through single authors by considering: a chapter of Macrobius that preserves matter known to have been in the lost eighth book of Aulus Gellius; the story - still invoked by theorists of the theatre - of the actor Polus who played the Sophoclean Electra holding the urn that contained his own son's ashes, which is preserved by Gellius alone; and the favourable accounts of Spartacus in Plutarch and other writers, which it is claimed all go back to Sallust.

Keywords. Aulus Gellius; Macrobius; Plutarch; Polus; Sallust; single authors; Spartacus; theatre; transmission. 